\title{
Collaborative intelligence for intensive care units
}

Kay Choong See ${ }^{1,2^{*}}$ (D)

\section{Dear Editor,}

The intensive care unit (ICU) is a rich and complex data environment, well-suited for artificial intelligence (AI) and machine learning techniques. Numerous AI applications are being developed for the management of critically ill patients [1], both before and during the COVID-19 pandemic [2]. However, it remains unclear how intensive care clinicians can benefit from AI. Learning from the business literature, the concept of collaborative intelligence can help to clarify how humans can synergize with AI [3]. For the ICU, three domains can be identified where AI can augment the human clinician, and vice versa (Table 1 ).

The first domain is related to accountability and risk mitigation, where AI amplifies human cognition while humans sustain AI [3]. The speed and consistency of digital systems allow AI to help humans perform continuous and rapid multi-channel monitoring, data harvesting, organization and analysis. Such abilities are particularly useful in the ICU, where critically ill patients quickly amass large quantities of clinical data, and clinicians are at risk of monitoring fatigue. Furthermore, AIdriven decisions can help corroborate human decisions. In return, humans can provide real-world stress testing of AI systems, including simulated adversarial attacks, which are intentional contamination of data aimed at causing AI malfunction. Additionally, humans can audit AI algorithms for accuracy and bias, enhancing confidence and trust in AI.

The second domain is related to sense-making, where AI interacts with humans in intelligible ways (i.e., explainable AI [4]) while humans help explain AI [3]. Rather than merely providing an output that substantiates human answers, AI can produce lists of salient features and probabilities for various diagnoses, predictions and actions, helping humans prioritize and justify decisions. To avoid the "black-box" effect, human clinicians can augment AI outputs by helping interpret these to lay-persons.

The third and final domain is performance augmentation, where AI embodies human skills while humans train AI [3]. Real-time AI-powered ultrasound systems to guide novices in image acquisition and interpretation are commercially available, e.g., Caption AI (Caption Health, Brisbane, CA). At the cognitive level, just like how human players train using computer chess engines, human clinicians can learn from AI-generated decisions and data summaries. Graph data science methods using multivariate time series can reveal novel visual relationships among patient characteristics, treatments and clinical evolution [5]. In turn, AI methods like reinforcement learning depend on real-life data and decision-making. Ultimately, implementation and scaling of AI solutions require human support for digital resources.

*Correspondence: kay_choong_see@nuhs.edu.sg

${ }^{1}$ Division of Respiratory and Critical Care Medicine, Department of Medicine, National University Hospital, University Medicine Cluster, National University Health System, 1 E Kent Ridge Road, NUHS Tower Block Level 10, Singapore 119228, Singapore

Full list of author information is available at the end of the article

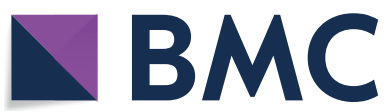

(c) The Author(s) 2021. Open Access This article is licensed under a Creative Commons Attribution 4.0 International License, which permits use, sharing, adaptation, distribution and reproduction in any medium or format, as long as you give appropriate credit to the original author(s) and the source, provide a link to the Creative Commons licence, and indicate if changes were made. The images or other third party material in this article are included in the article's Creative Commons licence, unless indicated otherwise in a credit line to the material. If material is not included in the article's Creative Commons licence and your intended use is not permitted by statutory regulation or exceeds the permitted use, you will need to obtain permission directly from the copyright holder. To view a copy of this licence, visit http://creativecommons.org/licenses/by/4.0/. The Creative Commons Public Domain Dedication waiver (http://creativeco mmons.org/publicdomain/zero/1.0/) applies to the data made available in this article, unless otherwise stated in a credit line to the data. 
Table 1 Collaborative intelligence for intensive care units

\begin{tabular}{|c|c|c|}
\hline Domain & How Al can augment human clinicians & How human clinicians can augment Al \\
\hline Accountability and risk mitigation & $\begin{array}{l}\text { Decrease risk of human fatigue by assisting with } \\
\text { continuous and rapid multi-channel monitoring, data } \\
\text { harvesting, organization and analysis } \\
\text { Provide support for human decisions }\end{array}$ & $\begin{array}{l}\text { Provide stress testing and simulated adversarial attacks } \\
\text { on Al systems } \\
\text { Provide safety netting for potentially biased algorithms } \\
\text { Provide medicolegal support for Al tools }\end{array}$ \\
\hline Sense-making & $\begin{array}{l}\text { Demonstrate clinical, laboratory and radiological fea- } \\
\text { tures contributing to an Al-driven result } \\
\text { Provide support for human decisions by computing } \\
\text { probabilities for the range of possible diagnoses, out- } \\
\text { comes and actions }\end{array}$ & $\begin{array}{l}\text { Provide explanations for Al-driven results to colleagues, } \\
\text { patients and family members }\end{array}$ \\
\hline Performance augmentation & $\begin{array}{l}\text { Provide clinical tools for diagnosis, risk prediction, triage, } \\
\text { treatment and other forms of decision-making } \\
\text { Compress data into interpretable summaries } \\
\text { Demonstrate data relationships with visualization } \\
\text { Provide automated evidence-based medicine search } \\
\text { and summaries } \\
\text { Provide automated guidance during imaging proce- } \\
\text { dures }\end{array}$ & $\begin{array}{l}\text { Feed Al with multisource data } \\
\text { Feed Al with relational information } \\
\text { Provide examples of human decision-making for training } \\
\text { of Al models } \\
\text { Provide support for the spread of digital resources- } \\
\text { including education of healthcare workers in digital } \\
\text { literacy_-for Al implementation and scalability }\end{array}$ \\
\hline
\end{tabular}

Al, Artificial intelligence

\section{Abbreviations}

Al: Artificial intelligence; ICU: Intensive care unit.

\section{Authors' contributions}

KCS contributed to study concept, design and drafting of manuscript. All authors read and approved the final manuscript.

\section{Funding}

No funding was required for this study.

\section{Availability of data and materials}

Not applicable.

\section{Declarations}

Ethics approval and consent to participate

Not applicable.

\section{Consent for publication}

Not applicable.

\section{Competing interests}

KCS has received honoraria and travel support from Medtronic and GE Healthcare.

\section{Author details}

${ }^{1}$ Division of Respiratory and Critical Care Medicine, Department of Medicine, National University Hospital, University Medicine Cluster, National University Health System, 1 E Kent Ridge Road, NUHS Tower Block Level 10, Singapore 119228, Singapore. ${ }^{2}$ Department of Medicine, Yong Loo Lin School of Medicine, National University of Singapore, Singapore, Singapore.

Received: 29 November 2021 Accepted: 30 November 2021

Published online: 14 December 2021

\section{References}

1. Gutierrez G. Artificial intelligence in the intensive care unit. Crit Care. 2020;24(1):101.

2. Chen J, See KC. Artificial intelligence for COVID-19: rapid review. J Med Internet Res. 2020;22(10):e21476.
3. Wilson HJ, Daugherty PR. Collaborative intelligence: humans and Al are joining forces. Harv Bus Rev. 2018;96(4):114-23.

4. Amann J, Blasimme A, Vayena E, Frey D, Madai VI, Precise QC. Explainability for artificial intelligence in healthcare: a multidisciplinary perspective. BMC Med Inform Decis Mak. 2020;20(1):310.

5. Martinez-Aguero S, Marques AG, Mora-Jimenez I, Alvarez-Rodriguez J, Soguero-Ruiz C. Data and network analytics for COVID-19 ICU patients: a case study for a Spanish Hospital. IEEE J Biomed Health Inform. 2021;25(2):4340-53

\section{Publisher's Note}

Springer Nature remains neutral with regard to jurisdictional claims in published maps and institutional affiliations.
Ready to submit your research? Choose BMC and benefit from:

- fast, convenient online submission

- thorough peer review by experienced researchers in your field

- rapid publication on acceptance

- support for research data, including large and complex data types

- gold Open Access which fosters wider collaboration and increased citations

- maximum visibility for your research: over $100 \mathrm{M}$ website views per year

At BMC, research is always in progress.

Learn more biomedcentral.com/submissions 